\title{
THE VARIATION OF THE QURAN RECEPTION 21ST CENTURY IN CENTRAL JAVA INDONESIA
}

\author{
Ayis Mukholik \\ Mr, University of Indonesia, Indonesia, ayismukholik@gmail.com
}

\begin{abstract}
In Indonesia, Al-Qur'an was been using by the majority of people as religious scripture. Al-Qur'an recitation is becoming a tradition and will always be an important part of religious behaviour. Al-Qur'an became social activity, such as memorizing, also competing it in international level, such as calligraphy art in Al-Qur'an and the tilawah. Al-Qur'an also becomes souvenir and jewel on mosque's wall, furniture and ornament from wood, glass, textile and any other. Research object will be Central Java as one of central of Islam's spreading in Indonesia at 14th century. This is proven by the numbers of Pesantren (Islamic Boarding), mosque with cultural Hindu's art and classic book which left by the ancestors or preachers. Islam was brought by Walisongo (Nine Preachers) with Sufism and cultural approach. They were using compromising model that invite people to convert to Islam by combining and mixing Islam with the teaching and cultural tradition which different or even appear opposition with Syariah/Islamic Law content. By that, rise many local expression on Islam, in this research focuses on local expression variety of Al-Qur'an. The question is, how variety of Al-Qur'an reception in Central Java, Indonesia at 21st century? Do acculturation of Javanese cultural with Islamic teaching is attached in people as religious experience and tradition? To know how the reception of Al-Qur'an in a certain people do, so there must know the local tradition and religious tradition which is still exist. Reception by mean is people approval, cultural expression on Al-Qur'an. For example, using of verse's piece for medication and salvation. Often, clean village agenda also use verse of Al-Qur'an to expel evil spirit. Indonesia, especially Central Java has so many religious practices which acculturate between 2 major traditions: Java and Islam. This practice is known by "the living Quran". Majority people in Indonesia are Moslem and cannot be away from religiosity. With this research, ethnography approach and sociology can be useful to know how people act toward Islamic knowledge. Variety of practice is being a treasure of Javanese Moslem that put private culture part to Islamic Thought.
\end{abstract}

Keywords: Reception, Holy Qur'an, Javanese Muslim.

\section{INTRODUCTION}

The discourse about Al-Qur'an tradition in Javanese society is really important to be discussed because this academic tradition has significant role for spreading Islamic teaching to all region in Nusantara. Islamic 
teaching spread used to be called as Islamization. Islamization did by two processes in the same time. Muslim society which stayed in Java region and becomes Javanese or local society embrace Islam and become Muslim (Ricklefs, 1930, p. 4).

Islam was came to Indonesia, especially Java was not easy, yet have to face with great rooted tradition that Javanese cultural environment which applied Pre-Islamic faith life style. The pre-Islamic faith is AnimismDynamism and, or Hindu-Buddha that already been faith system of villages in Java. Geertz mentioned Islam which faced with the tradition and Primitive Islam, Mystic of Islam, Marginal Islam, Traditional Islam and Islam that away from resource in Mecca, Arab region (Geertz, 1960, p. 5).

But, this conclusion was been rejected by researcher due to assumption that Islam which united with Javanese tradition cannot take off the true identity from Mecca. As written in Woodward's thesis that Islam has a big role in transforming Javanese tradition. In his perspective, Islam in Java is not defiance yet Islamic varieties as it founded in other Islamic spread regions (Woodward, 2011, p. 4).

Islam, even though has to face the Javanese tradition, but it still has the network with Middle East. So, Islam cannot be separated from where it came in. Islam has to absorb and adapt with the society tradition. It has to strive with the high culture. Java is rigid environment with faith tradition and Hindu-Buddha culture and acculturates with the aspects of Animism-Dynamism which influence spiritual life and people morality. Also with the structure and kingdom system which build by the ideology platform and Hinduism-Buddhism philosophy.

This situation is the Islamic spreading background to Java Island with the different patterns through long dialogue to produce the configuration of socio-culture in order to suit the Islamic tradition with old-tradition that stayed long time ago.

Those both cultures are able to collaborate to shape acculturation. The platform from both cultural values is religious-magical that shape social system and cultural system called Javanese Islam types.

That's why, preach model that can be useful is compromise preach model, which invites to Islam with the way to arrange or mix Islam with the different teaching or cultural tradition or even appear as opposition with the sharia content (Ahmad Khalil, 2008, p. 14). Islam was facing the tradition power and strongly live in society, so Islamization in Javanese land conducted with the acculturative approach and full-tolerance. Thus, the method or preach pattern which conducted by Walisongo. They use several traditional tools like bedug, gamelan, wayang and rebana to attract people (Kees Van Dijk, 2015, p. 221-224).

Based on Islamization history in Indonesia, Al-Qur'an is the main book in Islam religion, accepted by Javanese as same as norms and tradition then arise reception varieties on it. Indonesian society used AlQur'an in daily activities and Javanese tradition covered by Islamic teaching. This phenomenon shows that Al-Qur'an is already became part of social life.

The discussion about Al-Qur'an and tradition in Indonesia already attract Islamic scholars even orientalist to conduct certain research with behaviour approach and people faith which called as anthropological sociological approach in Al-Qur'an studies. The orientalist whom interested to use this approach is Ingrid Mattson with the book is The Story of Qur'an (2008) and Anna M. Gade with her masterpiece The Qur'an: an Introduction (2010) and perfection makes practice (2004) and Anne Rasmussen in her book Women, the Recited Qur'an, and Islamic Music in Indonesia (2011).

Mattson in her book explains cultural aspects which involve verses of Al-Qur'an: begin how she memorized, wrote, taught, became decoration (calligraphy and architecture), translated and applied by Moslem, so it can be in the life cycle of Moslems. She, in example tells that there are verses of Al-Qur'an which said by Moslem spontaneity, so unleash from its excellencies, Mattson is not discussed Musabaqah Tilawatil Qur'an (MTQ), using verses of Al-Qur'an to medication of diseases, both physic and psychic, using verses of AlQur'an for certain ceremonials and using for talisman of Al-Qur'an for another activities. These practices can be found in Indonesia.

Anna M Gade in her book, she measures how far the power of Al-Qur'an influences daily activity, especially in moral transformation. Then many people use Al-Qur'an in every usage. Rasmussen study is more focus to aspect like Islamic music, including Tilawatil Qur'an (the recitation of Al-Qur'an), duff music and another music which have Islamic nuance. She also gives emphasize to recitation musicality of Al-Qur'an when it competed in the MTQ.

So that is why, the researcher puts attention to trend development in Al-Qur'an studies by focussing Central Javanese reception in the 21 st century. 


\section{SCOPE ROOM OF AL-QUR'AN RECEPTION AND LIVING QUR'AN}

In Indonesia, Al-Qur'an since long time ago already became religion text which used by majority people. Tradition of reading Al-Qur'an was always becoming the most important part of their variety behaviour. AlQur'an becomes a tool on social activities, the tradition of memorizing until competing in international level and also calligraphic art of Al-Qur'an and the Tilawah (Abdullah Saed, 2008, p. 84).

\subsection{The Meaning of Al Quran Reception}

The terminology of "reception" in Webster dictionary has 2 meanings: 1) the act of receiving; receipt; admission; as, the reception of food into the stomach; the reception of a letter; the reception of sensation or ideas; reception of evidence. 2) Acceptance, as of an opinion or doctrine. Philosophers who have quitted the popular doctrines of their countries have fallen into as extravagant opinions as even common reception countenanced (Webster-dictionary.org).

Al-Qur'an is the first resource of law in Islamic faith. In epistemology, Al-Qur'an is defined as the perfect reading (Quraish Shihab, 1996, p. 3). In terminology, it defines Al-Qur'an like usual meaning that Allah's revelation sent by Gabriel the angel to Muhammad without any changes in redaction. Prophet of Islam, Muhammad peace is upon him, appointed to send the revelation of Allah regularly, which means impossible to corrupt the content by adding, reducing or changing/ qath'i al wurud (Quraish Shihab, 2007, p. 188).

Al Quran is believed by Moslem as Allah's word which being kept the holiness so the values in it contain the direction for all human kind. Quraish Shihab says that Al-Qur'an is the direction based on history of the revelation and covered the direction on faith, morality and Islamic law which explains in universal spirit way. He also clarified that Al-Quran as the direction is the most important function of Al-Qur'an. (Qurasih Shihab, 1999, p. 30)

Guidance material contained in the verses of the Qur'an as Qurasih Shihab describes, summarized into eight categories that aim to improve the quality of private and public. Those eight points are the teachings of cleansing mind and soul of shirk (believing in many gods), the pattern of life which is loaded with fair human values and civilized, the unity amongst humans, an invitation to think and work, poverty eradication materially and spiritually, grounding the justice, moderation between capitalism and socialism and awareness of the importance of science and technology.

One of Al-Qur'an principle is related with time and space changing (Shalih Fi Kulli Zaman wa Makaan). This concept declared that Al-Qur'an is able to solve all problem of human from time to time, so the reader always use it in daily life in many ways. Beside, to get the knowledge, they believe by applying can get the virtue from God.

From the reception definition and Al-Qur'an above, it can be extracted the great definition that Al-Qur'an reception is how Al-Qur'an as text being received or accepted by Muslim and how they give the reaction on Al-Qur'an.

The object of people reception on Al-Qur'an is like how Al-Qur'an read, written, memorized, taught, practiced, became calligraphic object and also used as ruqyah (formula of prayer to exorcize) and talisman by certain society. Al-Qur'an was also received as a way of art expression. Al-Qur'an became souvenir or decoration on the mosque wall, tools and ornament of woods, glass, textile and many others. While the practice in the society which relates to Al-Qur'an application can be called as the living Qur'an.

\subsection{The Meaning of Living Quran}

The Study about Al-Qur'an reception is related strongly with the living Qur'an discourse. If we can understand it humbly, living Quran is Al-Qur'an's text which lived in the society. In this study, Amin Al-Khulli placed as Dirasah Maa Hawla Al-Qur'an that means the studies which placed the things outside the text of Al-Qur'an. This concept gives an attention to society response on text and the result of certain translation, like traditionalize chapter or verse reading on en event or certain religion social ceremony.

Living Qur'an tries to see the relation between Al-Qur'an and the Islamic society in a certain region and how Al-Qur'an is faced by attitude theoretically and practiced in daily life.

So that, we can sum up that living Qur'an is the study about the Al-Qur'an but not focus on textual existence, more to study about the social phenomenon which born by Al-Qur'an presence in a certain geographic region and time.

For the studies is social phenomenon about Al-Qur'an, especially in Central Java, one of province in Indonesia, so the study focus is on Javanese Muslim deeds which relates to Al-Qur'an. Absolutely, what they 
do, reflect on the varietive understanding of Al-Qur'an between groups in society, that is coastal area inhabitant and Java villagers. This because Indonesia has so many ethnic, race, culture, and island, so the way they present Al-Qur'an are different.

The cross between Al-Qur'an and culture were becoming a discourse that attracts Muslim scholars in Indonesia. It is signed by several researches as First, A. Jajang Rohmana "Memahami al-Qur'an dengan Kearifan Lokal: Nuansa Budaya Sunda dalam Tafsir al-Qur'an berbahasa Sunda" (Jajang, 2014, p. 79-99). In his writings, he gives the big picture of Sundanese cultural which been found in Sundanese translation. He found at least 3 things which sign of Sundanese culture that becomes local reception character in Sundanese translation. There are, language level usage or speech levels (undak, usu, basa), traditional idiom and Sundanese natural metaphor. In Sunda area, Muslims receive their Islamic identity and the Sundanic identity as two existences which contain and adapt each other. In the same manner as happened to Javanese society, in Sundanese region, Islam easily fused and possessed (awor, nyosok jero) to Sundanic identity.

The seconds, book by the title "Tafsir Al-Qur'an Nusantara Tempo Doeloe" (Evan, 2009, p. 147). Evan wrote about the struggling between Al-Qur'an and culture. The religious life of Javanese Muslim is not being rid of vernacular process. It's an effort to translate Islamic teaching (AI-Qur'an) that translated and wrote into local language and local script (jawi, pegon) long ago before 18th century. Vernacular process conducted by translating Al-Qur'an verses into local language and the giving the additional explanation or exegesis by using local language and inserting cultural values in it.

The thirds, Imam Muhsin's thesis which entitled Tafsir Al-Qur'an dan Budaya Lokal: Studi Nilai-nilai Budaya Jawa dalam Tafsir Al-Huda Karya Bakri Syahid. He explains that Tafsir Al-Huda is able to accommodate Javanese way of life which relates to human existential as God's creation, as individual, as social creation as same as the principals in Al-Qur'an's verses (Imam Muhsin, 2008, p. 2-16).

\subsection{Religion Characteristic of Central Java Society in Indonesia}

Geographically and culturally, Central Java is one of province which located in the heart of Java Island and becoming Java core culture. With the width of region $32.548 \mathrm{~km} 2$, this province has dense number of people approximately 39.298.765 inhabitants. The reason chooses location for research because of the locus of spreading Islamic teaching at the first time in Java Island.

Islam is come first for entering coastal region to have a dialogue about Islamic teaching principals which brought along with local culture. Coastal area is the place where capable to make a map in order to spread Islamic teaching because in the 16th-17th century, the location is not only for political core and economics activity, but also become the central for spreading religion teaching and Islamic culture, so that Islamization process to another deep regions run well. Woodward was wrote many shapes of Islamic influence for Java tradition as it sighted on several opus like Babad Tanah Jawi, Serat Centini, Serat Cebok and many others (Woodward, 1952, p. 34-35).

Islam was started and developed in Northern coast and succeeded build new central civilization that then have a great contribution in gave birth Javanese Islamic academics tradition, build new centrals of society, like building Pesantren. Through this Pesantren, Islamic educational system can be developed easily both verbally by preach in forums and writings such as kitab kuning (book of local Islamic Literature).

Pesantren is assumed as a great tradition which one of the purpose of the education is transforming Islamic teaching that usually conducted traditionally by Arabic classic books (al-Kutub al-Mu'tabarah) those majority written few centuries ago before Islam enters Indonesia. The Pesantren tradition seems like Sufism with worshiping, faith and prayer (Martin Van Bruinessen, 1999, p. 17-22).

Nevertheless, the religious thinking pattern in Javanese society is sufistic life (purifying heart). They way more inspired by tasawuf (mysticism in Islam) manner from Javanese Islam which humble, taken for granted, not lives in luxury and keep the harmony along with another society.

Javanese society is more flexible and adaptive in accepting Islamic teaching which entered without leaving the rooted-tradition. In this context, Islamic values tried to be adaptable in religious life by inserting Javanese culture. So, cultural activity of Javanese is religious because shaped and influenced by Islamic teaching values.

\section{VARIETIES OF AL-QUR'AN RECEPTION IN THE SOCIETY}

Interaction with the Al-Qur'an is kind of religious experience which often saw in Muslim society. In Arabic, the famous term is kaifa nata'amal ma'a al-Qur'an (how we can interact with the Al-Qur'an). This practice already 
rooted in Muslim society because Al-Qur'an is able to give the direction, guidance and inspiration to those who read, understand the content also apply it in life.

Muslim also believes that Al-Qur'an has a power to cure and change the morality into something positive. The power of Al-Qur'an in society tradition covers ritual, medication and another application.

There are varieties of reception in society towards AI-Qur'an appear because of people behaviour which varies because the tradition, theological stream and it's psychological. Another aspect of tradition has great influence on vivifying Al-Qur'an.

The true picture of how Muslims response the holy book was been existed since Prophet (peace be upon him) and the Shahabah (friend of Prophet), between memorizing tradition and majlis ta'lim which studies on Quran exegesis. The theory is developed by Nevid Kermani. He studies about Al-Qur'an reception by the first generation of Islam.

According to researcher statement, Moslem society in Indonesia has special character in receiving Al-Qur'an from generations to generations. The phenomenon is clearly sighted on social activity that mirroring everyday life of the Al-Qur'an. To see how Al-Qur'an is inspiring in the life on 21st century, so there is needed to categorize Al-Qur'an reception model.

On a great line, Indonesian Moslem society reception on Al-Qur'an is divided to 3 varieties, Al-Qur'an reception through oral, written and action.

\subsection{Al-Qur'an Reception through Oral}

Indonesian society expresses the attention on Al-Qur'an through oral / verbal. Moslem who lived in Central Java on the 21 st century keep the religious tradition then renew as relevant as era development. In their reception through oral are:

\subsubsection{Al-Qur'an Recitation.}

The recitation has becoming tradition of society since Islam enters Indonesia for the first time on 17th century (another versions said that the first time were 7th, 12th or 16th century). The children used to read it in every single evening in surau (small mosque), TPA (Quranic School for Children) or their home. When Pesantren established, the reciting tradition conducted regularly. Santri (student of Islamic Boarding School/ Pesantren) also take the very quiet places, such in grave of Walisongo to be deep in reading and memorizing the Holy book of Quran.

The children have been introduced the basic science of Quran since they were 3 years old. In past time, people took a long time to be able reading Quran. But now, many methods found to learn quickly reading Holy Quran.

Table1. The Variation of Quran Learning Method in Indonesia which exist to 21st Century

\begin{tabular}{|c|c|c|c|c|}
\hline No & Method & Page & Writer & Other Information \\
\hline 1 & Qira'ati Method & $\begin{array}{c}10 \\
\text { volumes. } \\
\text { In every } \\
\text { volume } \\
\text { consist of } \\
32 \text { pages }\end{array}$ & Salim Zarkasyi & $\begin{array}{c}\text { This method has been } \\
\text { developed in Quran } \\
\text { Educational Institution in } \\
\text { Semarang, Central Java } \\
\text { since 1970. }\end{array}$ \\
\hline 2 & Iqra' Method & $\begin{array}{c}6 \\
\text { volumes. }\end{array}$ & As'ad Humam & $\begin{array}{c}\text { The very new edition has } \\
\text { been summarized to be } \\
\text { just 1 volume consist of 36 } \\
\text { pages }\end{array}$ \\
\hline 3 & $\begin{array}{c}\text { Yanbu'ul al-Quran Book } \\
\text { Method }\end{array}$ & $\begin{array}{c}8 \\
\text { volumes }\end{array}$ & $\begin{array}{c}\text { Educational Institution of } \\
\text { Quran Memorizing in Kudus }\end{array}$ & $\begin{array}{c}\text { This book has been most } \\
\text { used in many Pesantren } \\
\text { entire North Java. }\end{array}$ \\
\hline 4 & $\begin{array}{c}\text { 10 Jam Belajar } \\
\text { Memaca al-Quran } \\
\text { method }\end{array}$ & $\begin{array}{c}1 \text { volume } \\
64 \text { pages }\end{array}$ & Sahroni Sunhadi Said & $\begin{array}{c}\text { This is very fast method in } \\
\text { learning Quran. It just } \\
\text { needs 10 hours to be able } \\
\text { reading Quran. }\end{array}$ \\
\hline
\end{tabular}


IJASOS- International E-Journal of Advances in Social Sciences, Vol. III, Issue 7, April 2017

\subsubsection{Al Quran as a Prayer}

Javanese Moslems have unique tradition in practicing Quran. They create formula from verses in the Quran as daily prayer. They usually send the pray to ancestors by chapter Yasin (83 verses) and chapter Waqiah (96 verses) on Thursday night. They believe that time was effective for a prayer to be answered. After Maghrib prayer, the religious leaders led people to i'tikaf (tarry in the mosque) by reciting those two chapters of Quran and tahlil.Tahlil is the formula of dzikr (form of worship) consists of beautiful sentence to praise God. For examples: Subhanallah (Glory be to Allah), Al-Hamdulillah (Praise to be Allah), Allahu Akbar (Allah is the greatest), Ayat Kursy, Shalawat to the prophet Muhammad peace be upon Him. The text of Ayat Kursy is founded in Quran chapter Al-Baqarah verse 255:

"Allah - there is no deity except Him, the Ever-Living, the Sustainer of [all] existence. Neither drowsiness overtakes Him nor sleep. To Him belongs whatever is in the heavens and whatever is on the earth. Who is it that can intercede with Him except by His permission? He knows what is [presently] before them and what will be after them, and they encompass not a thing of His knowledge except for what He wills. His Kursy extends over the heavens and the earth, and their preservation tires Him not. And He is the Most High, the Most Great" (Ayat Kursy/ chapter al-Baqarah verse 255).

\subsubsection{Tradition of the Death of Man}

People has the tradition to recite al-Quran chapter Yasin, chapter Waqiah and tahlil on the 7th day of the death of a man and co memorize it again on 40th day, 100th day, and 1000th day. Societies of Javanese Muslim gather in house who got the death. The host provides the traditional food to take home.

\subsubsection{Art of Tilawah}

One of Muslim society expression of Quran is it's recitation with art of tilawah. Tilawah is method of Quran reading with good voice. Arabic melody art for reading Quran was called Maqamat. There are many model of this melody: Bayati, Rast, Sika, Soba, Jiharka, Hijaz, and Nahawand. This variation of melody is caused by style of Arabic dialectic. Now days, technology makes the melody of Quran can be accessed in many medias such as CD, cassette or by online. One of Qari' (Reciter of Quran Melody), Abdul Basit Abdul As-Shamad has inspired other international Qari' around the world to make innovations and deliver their own art from country.

The tradition of Tilawah has become the opening of every social event. Like, hajatan such as marriage party, khitan (circumcision party), aqiqah (celebration of baby), celebration for pilgrimage and any big events of Islamic tradition like tabligh akbar Maulud Nabi (the birth of Prophet Muhammad SAW), Isra' Mi'raj, the Islamic New Year (hijria), and Nishfu Sha'ban (Middle of month Sha'ban).

\subsubsection{Tahfidzul Qur'an}

Pesantren has become the media of people in Indonesia to memorize the Al-Qur'an. There are many pesantren whether classic or modern which offer memorization of Al-Qur'an in a short time, it could be 5 months, 10 months, or 2 years.

Based on the traditions of Islamic law, the Quran memorization is included righteous deeds are judged fardlu kifayah (individual obligation). So Moslems increased his faith as recited Quran. Therefore, the influences of the Quran not only on personal practice but communal. A Hafidz who memorize the Quran have responsibilities that make up the social order. Classic literatures describe their morals on society. One of ethics in memorizing the Quran is the questions of how to teach or read the Qur'an became livelihoods involve receiving wages, Hadith tells us that it is not for worldly affairs, but for the good of the Quran itself (Anna M Gade, 2010, p. 173).

\subsubsection{The competition of Al-Qur'an artistic recitation}

This event first conducted on 1940 by Indonesian government. This agenda values are very positive activity for Islam dynamics in Indonesia toward Al-Qur'an studies, so now the event still exist. In the 21st century, Indonesia gave birth for thousands talent Qari whom won over many competitions of artistic recitation of AlQur'an in the international level. On 2015, MTQ was stepped on 43th years old.

\subsection{Al-Qur'an Reception through Written}

The result of acculturation of Javanese traditions also influences many kind of Al-Qur'an reception within the 21st century society. Up till now, Javanese Moslem keeps the tradition from generations to generations textually. As the sign of love towards Al-Qur'an, Javanese Moslem wrote the verses of Al-Qur'an become the art of calligraphy (beauty written skill in Arabic). In Wonosobo, Al-Qur'an calligraphy made giant by the 
unique attribute as Indonesia specialty. Verse of Al-Qur'an also wrote beautifully as wall decoration in the house, mosque, hospital, porcelain. Often, the piece of verse of Qur'an printed as sticker accessories, key holder, marriage invitation and wooden sculpture. This calligraphy also held in competition between students in elementary school to university.

Table 2. Calligraphy Competition

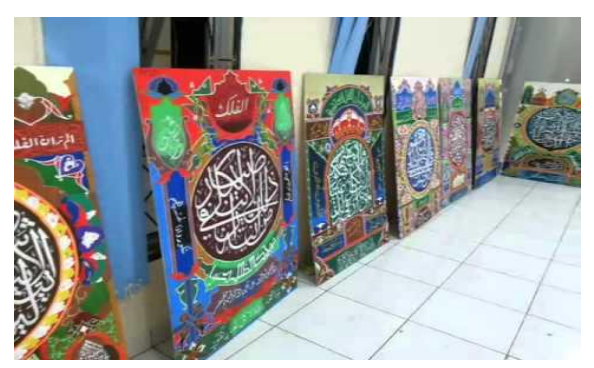

Table 3. Tradition of writing giant Quran in Wonosobo

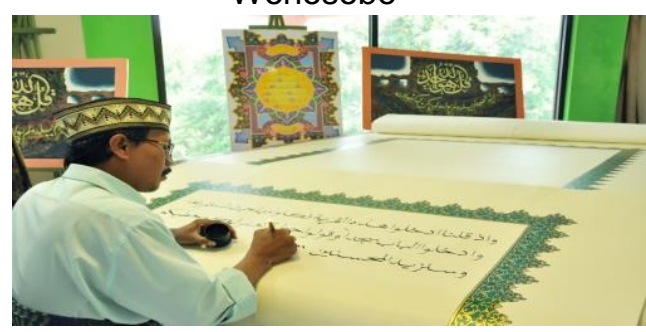

Kiai (religious scholars) have used al-Qur'an's verses for medications like chapter al-'Ankabut and chapter Luqman to help healing Malaria diseases. The verses in the Quranic chapter are written in a piece of paper and put in a glass of water and then drink the water.

\subsection{Receptions of al-Qur'an through Actions}

In Javanese society, al-Qur'an's verses are used to medical purposes, soul therapy, even a medium to keep a new house from calamities and to expel devils.

Traditionally, societies still believe in the power of al-Qur'an. They usually see religious scholars and ask them to recite al-Qur'an for several purposes like to make their trades become in demand, to look for marriage partner, and to heal patients who can't be handled by doctors in a hospital. Al-Qur'an also becomes amulet brought everywhere when taking a journey. Involving al-Qur'an in daily can bring positive impacts on psychology like feeling still, feeling closer to God, and easy to face any problems.

The strength of the Quran works in humans outside the field of science, which is applied in the treatment of the Prophet (At Tibun Nabawi). Traditional treatment using the Quran reaps doubt and controversy in the contemporary era. The first reason is many deeds that made innovation (heresy), which is distant from the original practice of Islam, even though this practice had been introduced in the past. Secondly, criticism of the old tradition that brings superstition, which is not based on Islamic principles or practice of such treatment, cannot be accepted by the modern medical community.

Talisman that uses verses of the Koran called the rajah or namimah. Some scholars of Islam forbid the use rajah for degrading the function of the Koran, but some scholars allow it. The reason is the Koran serves as a drug / antidote for body and spirit (Yusuf Al-Qardhawi, 2001, p. 262).

Reception of Quran through action trends embark in contemporary such as political sphere. For example, the usage of 'religious language' appears in politics as justification and motto in campaign.

In films industries, Al-Qur'an verses are used to religious sense and spiritual content. This model can increase the rates of the films. Based on this positive trend, there are many television programs take benefit from it like Uji Nyali (Guts Test), Pemburu Hantu (Ghost Hunter), Dua Dunia (Two Worlds) etc. These television programs present a scenario where evil spirit obsesses humans but al-Qur'an defeats them.

The implementation of al-Qur'an in Javanese society becomes the strong appeals. A lot of al-Qur'an's expressions in society are influenced by local tradition. Al-Qur'an which interacts with the given traditions produces good deeds that can strengthen person's faith, religiosity, and morality.

\section{CONCLUSION}

The trends of Al-Qur'an in Central Java society from the beginning of Islam until this contemporary era develop dramatically. Al-Qur'an is the main guidance used many aspects of life like education, economy, health, politics and culture. In villages or cities the written, spoken, and behavioural expressions of al-Qur'an are easily to be found. Accordingly, the inspirations obtained from al-Qur'an transform into local wisdom, arts, creativity, and local based- Islamic civilization.

Living Qur'an constitutes an alternative paradigm for Islamic studies and sociology or religious anthropology since this study examine religious phenomena in social life. 


\section{ACKNOWLEDGEMENT}

This research was financially supported by LPDP, institution of education fund manager, Ministry of Finance, Republic of Indonesia

\section{REFERENCE LIST}

Bruinessen, M. V. (1999). Kitab Kuning, Pesantren dan Tarekat. Mizan.

Dijk, K. V. (2015). Dakwah, The Dissemination and Indigenous Culture of the Islam. 2 (154).

Gade, A. M. (2010). The Qur'an: An Introduction. Oneworld Publication.

Geertz, C. (1960). The Religion of Java. The Chicago of University Press.

Khalil, A. (2008). Islam Jawa: Sufisme dalam Etika dan Tradisi Jawa. UIN Malang Press.

Mattson, I. (2008). The Story of the Qur'an: Its History and Place in Muslim Life. Blackwell

Nurtawab, E. (2009). Tafsir Al-Qur'an Nusantara Tempo Doeloe. Ushul Press.

Qardhawi. Y. A. (2001). Fatwa-fatwa Kontemporer. Gema Insani Press.

Rasmussen, A. K. (2010). Women, the Recited Qur'an, and Islamic Music in Indonesia. University of California Press.

Ricklefs, M.C. (2012). Islamisation and its Opponents in Java: A Political, Social, Cultural and Religious History, c.1930 to the Present. NUS Press.

Rohmana. A. J. (2014). Memahami al-Qur'an dengan Kearifan Lokal: Nuansa Budaya Sunda dalam Tafsir al-Qur'an berbahasa Sunda. Journal of Qur'an and Hadith Studies. 3 (1).

Saeed, A. (2008). The Quran: an Introduction. Routledge.

Shihab, M. Q. (1996). Wawasan Al-Qur'an: Tafsir Maudhu'i atas Pelbagai Persoalan Umat. Mizan.

Shihab, M. Q. (1999). Lentera Hati Lentera Hati: Kisah dan Hikmah untuk Kehidupan. Mizan.

Shihab, M. Q. (2007). Membumikan Al-Qur'an: Fungsi dan Peran Wahyu dalam Kehidupan Masyarakat. Mizan.

Woodward, M. (1952). Islam in Java. The University of Arizona Press.

Woodward, M. (2011). Java, Indonesia, and Islam. Springer Dordrecht Heideiberg.

http://www.webster-dictionary.org 